\title{
A rapid screening test by the latex antistreptolysin $O$ test for streptococcal infections in CMS Teaching Hospital, Bharatpur, Nepal
}

\author{
B.L Dewasy ${ }^{1}$, Y.I.Singh ${ }^{2}$, B.K.Jha ${ }^{3}$, J. Kapil ${ }^{4}$ \\ ${ }^{1,3}$ Lecturer, ${ }^{2}$ Professor \& Head, Dept. of Microbiology, College of Medical Sciences-Teaching Hospital, Bharatpur, Nepal, \\ ${ }^{4}$ Associate Professor, Dept. of Microbiology, Sikkim Manipal Institute of Medical Sciences, Sikkim, India.
}

\begin{abstract}
:
Streptococcus pyogenes (group A Streptococci) infection is diagnosed by either bacterial culture or serological test. For the serodiagnosis, antistreptolysin O (ASO) and antideoxyribonuclease B (DNAase B) are the most widely accepted tests. To measure the antibodies (ASO) of Streptococcus with the help of Rapitex antistreptolysin as a screening test is widely used in cases of suspected streptococcal infections and its sequelae. There were 4230 serum samples of rheumatic fever, glomerulonephritis, rheumatic heart disease and rheumatic arthritis. They were tested for Antistreptolysin O (ASO) antibodies by latex agglutination test. The test is very simple, cheap, rapid, convenient and reliable. Correlation with the clinical diagnosis is possible for routine use.
\end{abstract}

Key Words: ASO, rheumatic fever, latex agglutination.

\section{Introduction:}

Streptococcal infections can be diagnosed by antibody tests. Three streptococcal antibody tests are available viz the antistreptolysin $\mathrm{O}$ titre (ASO), the antideoxyribonuclease-B titre (anti-DNAase-B, or ADB), and the streptozyme test. ${ }^{1}$ The most popular and standardized serological test is still ASO. ASO is not only useful in the diagnosis of streptococcal infections or complications, but also in the follow-up process and in evaluating the effectiveness of treatments. ${ }^{2}$ There is worldwide distribution of the rheumatic fever (RF) and acute post-streptococcal glomerulonephritis. They are the sequelae following the streptococcal infections resulting in an important health and economic problems. ${ }^{3}$ As ASO is not always elevated after streptococcal infection or sequelae, it is

Correspondence: Mrs.Dewasy BL

E-mail:dewasy.laxmi@gmail.com necessary to add the alternative serological test. Since ADB has a longer half-life than ASO, it can be a valuable tool in the diagnosis of remote past infections. ${ }^{4}$ Streptolysin O is antigenic and antistreptolysin O appears in serum of streptococcal infections. ASO test is now done by the latex agglutination. ${ }^{5}$ For the diagnosis of non-suppurative sequelae of Streptococcus pyogenes, ASO test is more widely used. The antistreptolysin O test (Gooder and Williams 1959) is used most frequently. Normal antibody test does not exceed 200 Todd units/ml. Streptococcal antibodies can be detected by the standardized ASO test. A commercial latex particle kit is available (Rapitex ASL, Behring). ${ }^{6}$ ASO titre of 200 units or more is significant in rheumatic fever. The ADB test was complicated. It lacked reproducibility and the reagents were difficult to obtain. With the development of 
B.L Dewasy et al, A rapid screening test by the latex antistreptolysin O test for...

immunochemical techniques viz turbidimetry or nephelometry, quantitative ADB analysis methods are available. $^{7}$

\section{Materials and methods:}

Serum samples were collected from 4230 patients between the periods of January 2003 to December 2009. Samples were collected in clean, sterile, small test tube from suspected streptococcal infections and its sequelae patients attending out-patients and inpatients departments in the College of Medical Sciences -Teaching Hospital in Bharatpur, Nepal. All the serum samples were tested by Rapitex ASO kit (ADivision of Span Diagnostics Ltd. Code no-25947). ${ }^{8}$ The reagents, accessories and instructions to follow were supplied with the kit.

Procedure Test serum and reagents were kept at room temperature before testing. $40 \mu \mathrm{l}$ of patient's serum within the circled area were placed on the clean and dry special glass slide provided in the kit. One drop of well mixed ASO latex reagents was added to serum. The reagent and serum using the applicator stick were mixed. The slide was rotated and agglutination observed after 2 minutes. Results were compared with positive control and negative control. ASO titre of the test samples was indicated by the corresponding value in IU indicated against highest serum dilution which gives positive agglutination within 2 minutes. ASO titre more than $200 \mathrm{IU}$ was considered significant.

\section{Results}

The 4230 serum samples were processed in clinical microbiology laboratory for detection of antibodies of streptococcus from patients who attended College of Medical Sciences- Teaching Hospital for suspected streptococcal infections. 1944 samples were positive and 2286 samples were negative during the period of January 2003 to December 2009.

Table-I: shows age and sex distribution of total number of cases. The highest rate 990 (23.40\%) of cases was found in the age group (10-20) years and lowest rate 510 (12.05\%) of cases was found in the age group (50-60) years.

Table-I: Age and Sex Distribution of total number of cases.

\begin{tabular}{cccc}
\hline Age (in years) & Cases (in percentage) & Male & Female \\
\hline 10 & $750(17.73)$ & 390 & 360 \\
$10-20$ & $990(23.40)$ & 210 & 780 \\
$20-30$ & $705(16.66)$ & 411 & 294 \\
$30-40$ & $595(14.06)$ & 286 & 209 \\
$40-50$ & $680(16.07)$ & 401 & 279 \\
$50-60$ & $510(12.05)$ & 271 & 239 \\
Total & 4230 & 2069 & 2161 \\
\hline
\end{tabular}


Table- II: shows positive cases of the age and sex distribution of ASO. Percentage of highest positivity was in the age group 10-20 years. The percentage of lowest positivity was in the age group 50-60 years.

Table- II: Age and sex distribution of ASO among positive cases

\begin{tabular}{cccccc}
\hline $\begin{array}{c}\text { Age } \\
\text { (in years) }\end{array}$ & \multicolumn{2}{c}{ Male } & \multicolumn{2}{c}{ Female } & \multicolumn{2}{c}{$\begin{array}{c}\text { Total No. of Positive sample: } \\
\text { (in percentage) }\end{array}$} \\
\cline { 2 - 5 } & $\begin{array}{c}\text { No of } \\
\text { patients }\end{array}$ & $\begin{array}{c}\text { Positive } \\
\text { cases }\end{array}$ & $\begin{array}{c}\text { No of } \\
\text { patients }\end{array}$ & $\begin{array}{c}\text { Positive } \\
\text { cases }\end{array}$ & \\
\hline 10 & 390 & 100 & 360 & 200 & $300(40.00)$ \\
$10-20$ & 271 & 105 & 239 & 160 & $265(51.96)$ \\
$20-30$ & 210 & 200 & 780 & 300 & $500(50.50)$ \\
$30-40$ & 386 & 195 & 209 & 110 & $305(51.26)$ \\
$40-50$ & 401 & 164 & 279 & 135 & $299(43.97)$ \\
$50-60$ & 411 & 170 & 294 & 105 & $275(39.00)$ \\
Total & 2069 & 934 & 2161 & 1010 & 1944 \\
\hline
\end{tabular}

\section{Discussion:}

ASO tests have, lately, been most widely applied in clinical laboratory, using semiquantitative latex agglutination, the hemolysis inhibition method, quantitative turbidimetry, nephelometry or even the rapid chemistry autoanalyzer. ${ }^{9}$ Fujikawa and Okuni observed that ASO elevation occurs only in $60 \%$ of rheumatic fever (RF). But after one more test is added either ADB or streptokinase test, they were able to diagnose RF with $95 \%$ accuracy. ${ }^{10}$ In this study, 1944 samples ware positive (more than 200IU/ml

for ASO titre). The percentage of positive streptococcal tests is correlated with the age of the child and was found in $35 \%$ of the arthritis patients aged 811 years. Patients with PSRA (post streptococcal rheumatic arthritis) lead to long duration of illness and had longer disease duration than those with transient arthritis. Hip involvement, inactive disease at 6 weeks and 6 months and negative ANA(Anti-Nuclear
Antibody) and HLA-B27 (Human leucocytes antigen) were more frequent in PSRA than in the JRA (Juvenile rheumatoid arthritis) patients. One-third of the patients with PSRA still had signs of streptococcal infection after 18 months. Carditis was only found in one child who had acute rheumatic fever. ${ }^{11}$

Susceptibility to rheumatic fever in certain individuals has been ascribed to a number of factors. These include genetic determinants, for example, HLAs and the presence of certain markers such as the B-cell alloantigens. One of the factors originally considered in rheumatic fever susceptibility is an innate state of immune hyperresponsiveness, particularly to streptococcal antigens. ${ }^{12,13,14,15}$ An alternate explanation to consider is that individuals in such an area develop in Grenada or possess an innate immune hyper responsiveness to streptococcal antigens. Whether the high rate of expression of rheumatic fever in certain populations is related to a high frequency of 
B.L Dewasy et al, A rapid screening test by the latex antistreptolysin O test for........

streptococcal infections or to that in combination with an innate state of hyper immune responsiveness to streptococcal antigens remains to be determined. ${ }^{16}$ Urdahl and his coworkers determined the serum antistreptokinase titres in the sera of nonrheumatic adult aboriginals in Australia, a population with a very high incidence of streptococcal infection. ${ }^{17}$ They found that the geometric mean titre of this streptococcal antibody was almost 20 times higher than that in nonaboriginal adults. This study, together with data derived from the present study indicates that the levels of the streptococcal antibodies in healthy populations can vary substantially, depending on the frequency of streptococcal infections in those populations.

\section{Conclusion:}

A number of variables should be taken into consideration while interpreting the results of streptococcal antibody titres in the context of their relationship to the epidemiology of group A streptococcal infections or the role of such infections in the pathogenesis of rheumatic fever. The titre of ASO is more in school going children 10-20 years age group. The lowest incidence is seen in 50-60 years of age group. The numbers of maximum positive male and female patients are in 20-30 and 10-20 of age groups respectively. There are necessities to consider the background frequency of streptococcal infection in certain populations when the streptococcal antibody titres of rheumatic fever and nonrheumatic populations are being compared. Differences in the distribution of the titres of antibodies between such populations will become apparent when the titres in nonrheumatic subjects from an area with a high incidence of rheumatic fever is compared to those of a similar population from an area with a low incidence of this disease. As the ASO test report can be given rapidly and test is correlated with clinical findings for routine diagnostic work, it is useful without depending upon other test.

\section{Acknowledgement:}

First of all I would like to thank \& praise to god for giving me this wonderful opportunity. I am immensely indebted to Dr.Y.I. Singh for his valuable suggestion $\&$ encouragement.

\section{References:}

1. WHO. Rheumatic fever and rheumatic heart disease. Report of a WHO expert consultation. Geneva. 29 October-1 November 2001. WHO Technical Report Series 2004; 923: 1.

2. Shet A, Kaplan EL. Clinical use and interpretation of group A streptococcal antibody tests. A practical approach for the pediatrician or primary care physician. Pediatr Infect Dis J 2002; 21: 420-6.

3. Ahmed S, Ayoub EM. Post streptococcal reactive arthritis. Pediatr Infect Dis J 2001; 20: 1081-2.

4. Ayoub EM, Nelson B, Stanford TS, Douglas JB, George A, John L, et al. Group A streptococcal antibodies in subjects with or without rheumatic fever in areas with high or low incidences of rheumatic fever. American society for Microbiology. Sept 2003; 10: 886-90.

5. Ayoub EM, Majeed HA. Poststreptococcal reactive arthritis. Curr Opin Rheumatol 2000; 12: 306-10.

6. Mackie SL, Keat A. Poststreptococcal reactive arthritis. What is it and how do we know? Rheumatology 2004; 43: 949-54.

7. Pacifico L, Mancuso G, Properzi E, Ravagnan G, Pasquino AM, Chiesa C. Comparison of nephelometric and hemolytic techniques for determination of antistreptolysin O antibodies. Am J Clin Pathol 1995; 103: 396-9. 
8. Span diagnostic Ltd. Latex agglutination slide test for the qualitative and semi-quantitative determination of ASO. Surat, India. 2003; Code no 25947.

9. Hostetler CL, Sawyer KP, Nachamkin I. Comparison of three rapid methods for detection of antibodies to streptolysin O and DNase B. J Clin Microbiol 1988; 26: $1406-8$.

10. Fujikawa S, Okuni M. The determination of ADNase-B titres. Jpn Circ J 1979; 43: 417-8.

11. Ayoub EM, Kotb M, Cunningham MW. Rheumatic fever pathogenesis. Streptococcal infections clinical aspects microbiology and molecular pathogenesis; Stevens DL and Kaplan EL: Oxford University Press, New York, 2000; 102-32.

12. Meiselas LE, Zinglae SB, Lee SL. Antibody production in rheumatic diseases, the effect of brucella antigen. $J$ Clin Investig 1961; 40: 1872-81.
13. Rejholec V. Incidence of rheumatic fever in relation to immunologic reactivity. Ann Rheum Dis 1957; 16: 23-30.

14. Stollerman GH. Hypersensitivity and antibody responses in streptococcal disease. streptococci and streptococcal diseases recognition, understanding and management. Wannamaker LM and Matsen JM, Academic Press, New York, 1972; 501-13.

15. Swift HF. Rheumatic fever. JAMA 1929; 92: 2071-83.

16. Klein GC, Baker CN, Jones WL. Upper limits of normal antistreptolysin $\mathrm{O}$ and antideoxyribonuclease B titres. Appl Microbiol 1971; 21: 999-1001.

17. Kim S, Lee NY. Asymptomatic infection by Streptococcus pyogenes in schoolchildren and diagnostic usefulness of antideoxyribonuclease B. J Korean Med Sci 2005; 20: $938-40$. 